\title{
4 \\ Movement of People and Money
}

On January 8,1748 , the Shengjing military governor Daldangga received a report that property belonging to a member of the Chosŏn embassy had been stolen as the group had passed Liaoyang, a city within Daldangga's jurisdiction. According to the initial report delivered through Korean interpreters, the victim was Sahwan, a Korean packhorse driver serving the embassy on its journey to Beijing. He was also a servant of Yun Changli, the Korean official in charge of the embassy's luggage. Sahwan reported what he had seen:

When we arrived near Wanbaoqiao, a man riding a horse turned up all of a sudden shouting out loud. My horse was so frightened that it ran away. I hurried to catch up with the horse and found it standing in front of a house. There I saw one of the two packages of silver [that the horse had been carrying] on the ground, but the other package was gone.... We asked [the people in the house] about the silver, but they said they didn't know about it. Later, my colleagues searched through the house and found the silver package hidden in a pile of sorghum. ${ }^{2}$

Sahwan pointed to Song Erdazi, a Qing subject living in Wanbaoqiao, as the prime suspect. Song's testimony was, however, very different from the Korean servant's presentation of the case:

When I had made a fire [inside my house] ... the Koreans appeared at the gate, asking for a light for tobacco. Near the gate was a pile of firewood; it was very windy on that morning, so I did not give it to them. Then they asked me the way, so I opened the gate. Upon coming in, however, they started talking all of a sudden about their lost luggage, rummaging through my house with one hand while tying me up with the other.... As the day dawned, the Koreans returned, insisting that their silver had been found in the pile of sorghum in my house and tying me up again. ${ }^{3}$ 
This incident, which later became known as "Korean Sahwan's false accusation of theft," was reported by Daldangga to the Board of Rites in Beijing and eventually to the Chosŏn court in Seoul, and it troubled the Qing and Chosŏn courts for several years to come.

This chapter discusses the Chosonn tributary embassy and their trade as the background of the Sahwan case and then examines the subsequent series of disputes involving the Shengjing military governor and the Chosŏn court. Two problems are of special concern here. First, the Qing and Chosŏn courts had established a tributary relationship that not only defined the nature of their political ties but also shaped their economic connections. Qing foreign policy guaranteed regular visits and the payment of tribute by the subordinate neighbor, and this regular ritual had an unexpected side effect: the creation of a variety of trading opportunities for Qing and Chosŏn merchants. Second, the empty buffer zone north of the Yalu River-maintained through the consensus of the Qing emperors and the Chosŏn kings - created a space and an opportunity for Koreans to make contact with local people in Qing territory. The frequent and regular contacts between the Chosŏn embassy and local Qing people led to the development of flourishing markets on the route from Fenghuangcheng to Shengjing.

In his analysis of the trade between Chosŏn Korea and Tokugawa Japan, James Lewis explains that "frontiers [such as Tsushima and Pusan] . . . [as] the sites of actual contacts" were as important as national centers in the formation of cultural perceptions and historical memory. ${ }^{4}$ If Tsushima and Pusan were the contacting locations between Chosŏn Korea and Tokugawa Japan, it was Fenghuangcheng and Shengjing where Qing China and Chosŏn Korea met. Details of actual contacts at the boundary near the Yalu River and the Qing northeastern margin, in fact, revealed unknown dimensions of Qing-Chosŏn relations. A centralized perspective on Qing-Chosŏn tributary relations assumes that the courts in Beijing and Seoul had a single, direct connection and portrays other contacts, which took place in the periphery, as trivial, marginal, and even abnormal. For Beijing and Seoul, whose shared primary interest was to maintain proper tributary rituals, the incident involving Sahwan and Song Erdazi was merely an annoyance for both sides. From the perspective of the periphery, however, the practice of paying tribute not only served to maintain the political hierarchy between the Qing emperor and the Chosŏn king, but also affected the development of physical contacts and commercial exchange between people from the two countries. The tributary embassy provided a legitimate opportunity for many Korean profit seekers to cross the Yalu River and enter Qing territory, as well as for local Qing merchants and ordinary people to benefit from trade with the Chosón embassy.

This chapter also demonstrates the ways in which the empty, restricted area near the boundary and the peripheral margins of the empire were commercialized by the tributary relations. Fenghuangcheng and Shengjing witnessed the growth 
and thriving of trade and transportation related to the Chosŏn embassy in the eighteenth century. Local Qing people and Chosŏn merchants alike took advantage of the vacancy created at the boundary and developed various ways to exploit trade opportunities in the area. On the other hand, the frequent contacts between Chosŏn visitors and Qing locals sometimes turned into conflicts, mostly over money, and minor arguments sometimes developed into serious tensions between Beijing and Seoul. The tributary relationship attracted people and money to the Yalu River, but in the end the resulting contacts and conflicts caused Qing authority to be enforced to the Chosŏn court in Seoul. Tribute and trade combined to commercialize the Qing-Chosŏn boundary and some parts of the Qing northeast margin, yet this process was limited and controlled by the asymmetrical relations between the Qing and the Chosŏn.

\section{THE CHOSŎN TRIBUTARY EMBASSY}

The 1637 peace treaty between the Qing and Chosŏn courts required the Koreans to send royal embassies to the Qing to celebrate the winter solstice, New Year's Day, and the emperor's birthday, in addition to paying an annual tribute to Beijing. In 1645, when the Qing capital moved from Shengjing to Beijing, the Manchus allowed the Chosŏn court to combine other embassies with the winter solstice embassy because of the lengthened tribute route. This became known as the annual tribute or the regular embassy. ${ }^{5}$ There were also various types of irregular embassies. ${ }^{6}$ The composition of any given embassy varied according to the specific obligations and duties of the party. The leading members of the embassy were court officials, including the chief ambassador (K. chóngsa), the vice ambassador (K. pusa), and the attendant secretary (K. sŏjanggwan). The chief ambassador was nominated from among members of the royal family or high officials, and he represented the Chosŏn king to the Qing emperor. The vice ambassador was in charge of the general office work of the embassy, while the attendant secretary supervised all affairs relevant to the embassy, notably regulations on smuggling. ${ }^{7}$ In practice, however, these high officials did not directly manage the tributary mission because they were not permitted to communicate with Qing officials at will; every discussion had to be conveyed through written memorials. Go-betweens from the Office of Interpreters (K. Sayŏgwŏn) dealt with all practical matters. The chief interpreter essentially managed the mission, from trivial transactions with local merchants during the journey to important discussions with Qing officials pertaining to rituals at the imperial court. High court officials were thus in actuality simply nominal representatives, whereas the interpreters were the actual managers of the embassy. ${ }^{8}$

Tribute embassies also included military guards (K. kun'gwan) and other minor officials. These individuals were in charge of keeping records of the tribute and other goods, hiring porters and carts for transportation to Beijing, and protecting 


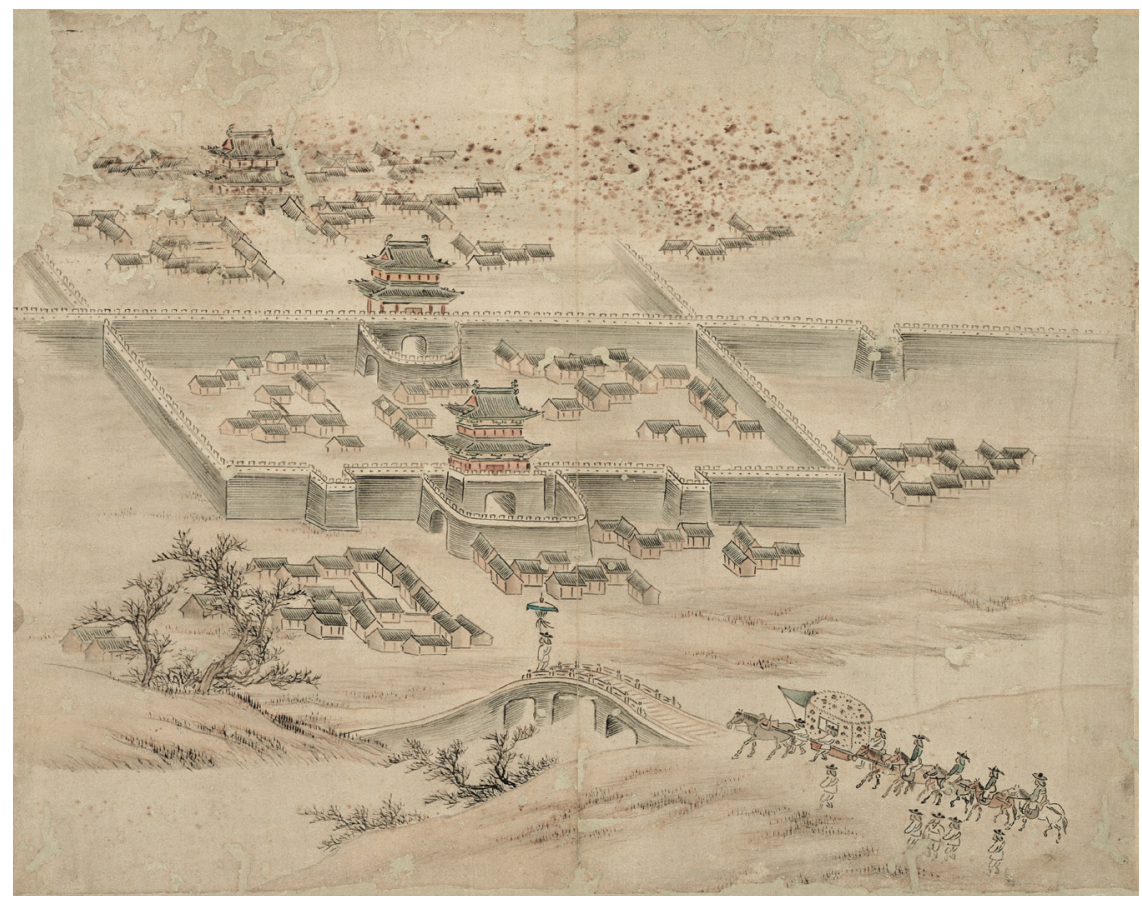

FIGURE 9. Sanhaegwan tongnasŏng (eastern rampart of Shanhaiguan), circa 1784. Hand scroll, ink and color on paper, $35.4 \times 45.3 \mathrm{~cm}$. From Yǒnhaengdo: Paintings of the Korean Envoys to Beijing during the Joseon Dynasty (Seoul: Sungsil taehakkyo Hanguk Kidokkyo Pangmulgwan, 2009), 12. Used with permission.

the luggage from the predations of the local porters. Besides such minor officials, numerous retainers also served the embassy. The Chosonn court sought to prevent an excessive number of people from joining the embassy, but since the number of retainers was not officially fixed, uncounted individuals were able to slip into the embassy entourage. ${ }^{9}$ In addition to retainers, there were painters, astronomers, physicians, and others who usually had some connection with embassy officials. Moreover, numerous people joined the delegation to carry the tribute and the luggage and to lead the horses during the journey. With all of these participants, the total number of people in an embassy often exceeded three hundred. ${ }^{10}$ By the early eighteenth century, the number had continued to grow; for example, 687 people crossed the Yalu River in the embassy of $1712 .{ }^{11}$

The Chosŏn embassy faced a long journey to the Qing imperial court. Traveling to Beijing from the Yalu River via Shengjing took a month..$^{12}$ Adding in the $1,070 \mathrm{li}$ from Seoul to the Yalu River, the journey time totaled more than six weeks. Including the customary monthlong stay in Beijing, the whole round trip took at 
least four months and could easily last up to five or six months. ${ }^{13}$ Although Beijing could be reached either by land or by sea, the land route was preferred because the sea-based journey was more dangerous. During the period when the Manchus were fighting Ming forces in Liaodong, the Chosŏn embassy traveled across the sea to the Ming court in Beijing. Once the Qing conquered China proper, the land route became the official travel route.

The final inspection of tribute embassies in Korea occurred in Ǔiju, a city on the Yalu River. A rigorous search for illegal group members was carried out, because the number of positions in the embassy was always significantly smaller than the number of people seeking entry into Qing territory. All of the tribute, people, and horses were checked. If anyone who was not officially listed was found in the embassy, the inspector in Uiju and the responsible embassy official were both punished. ${ }^{14}$ However, this inspection was often meaningless, since no matter how meticulous the controls, it was impossible to prevent all illegal crossings. Pak Chiwŏn (1737-1805), who participated in the tribute embassy to Beijing for the commemoration of the Qianlong emperor's seventieth birthday in 1780, provides us with a description of the stunning sight of the embassy at the shore of the Yalu River. ${ }^{15}$ Pak was particularly astonished by the great hassle created by the inspection, as embassy officials searched every item of luggage in order to prevent smuggling:

People are asked for their name, residence, age, facial features, height, et cetera. The inspectors of the embassy and the Üiju office examine every single piece of luggage to check for any illegal items, such as gold, silver, pearls, ginseng, furs, or weapons. Attendants and servants take off their shirts and pants and open their luggage to show to the officials. Bundles of linens and clothes and various boxes are scattered all around the shore. Without these inspections, there is no way to prevent smuggling. However, the inspections inevitably create great inconvenience. Nonetheless, even this inspection is nothing but a ritual. Since the Ǔiju merchants sneak across the river prior to the inspection, what effect does it really have? ${ }^{16}$

Pak was surprised again after crossing the river. On his first night in Qing territory, he witnessed people setting up their tents to spend the night in an open field; others were busy cooking meals and tending to horses. Instead of viewing an unspoiled territory, as the Yongzheng and Qianlong emperors might have expected, Pak found a scene reminiscent of any common village. ${ }^{17}$ Pak's vivid descriptions of the scenes at the Yalu River seem to contradict conventional assumptions about the Qing northeast, a region that held special meaning and value for the Qing imperial court and to which access was therefore supposedly rigorously prohibited. This sacred birthplace of the Manchus was supposed to be protected from all intruders, whether coming from China proper beyond Shanhaiguan or from Korea across the Yalu River. However, Pak's group of Chosŏn emissaries were left to their own devices for the first night after crossing the Yalu River and were not met by Qing officials until the next day. 
After crossing the Yalu River, the Chosŏn embassy was led to pass through the designated gate at the foot of the Fenghuang mountain. This first Qing gate, which Koreans called Chaengmun, was located along the Willow Palisade, thirty li away from Fenghuangcheng, the Qing administrative office that was closest to the Chosŏn. The gate was $90 \mathrm{l} i$ away from the Yalu River and $120 \mathrm{li}$ from Ǔiju. ${ }^{18}$ Since there were no postal stations between the Yalu River and the gate of Fenghuangcheng, the embassy had to camp out for two days before arriving in Fenghuangcheng. Korean authors of travel diaries about journeys to Beijing often remarked that they entered Qing territory by crossing the Yalu River, but there was, in fact, an uninhabited area between the Yalu and the Qing gate. Pak Chiwŏn noted that when he crossed the river, the land seemed abandoned:

The land near Jiuliancheng has ... not only high mountains and deep waters, but also wide fields and rich woods. I expected to see a big village where houses are so crowded that the residents can hear each other's dogs and chickens. The land is seemingly very fertile and suitable for reclamation. ... It could support the establishment of a huge military garrison. However, both we [the Chosŏn] and they [the Qing] have abandoned it to make an empty land [K. han'gu]. ${ }^{19}$

Pak's description corresponds with Marion Eggert's explanation that "the Üiju border was considered a tripartite form, consisting of first the Yalu River, then a stretch of wilderness, and finally the palisade with its gate." ${ }^{20}$ What Pak found, then, was not a clear-cut line dividing two neighbors; rather, it was a zone or a thick line. The land near the Yalu River remained empty, as the Qing and Chosŏn courts had agreed, but it also created unintended confusion about the exact limits of the two countries' territories, at least in the eyes of Korean travelers. While crossing the Yalu River, Pak Chiwŏn encountered a group of local people sailing across the river on their way back to Fenghuangcheng after logging timber in Changbaishan. ${ }^{21}$ According to the Qing restriction policy, such a violation of the sacred mountain was a serious crime, but it nonetheless took place in front of the Korean visitors' eyes. Near Fenghuangcheng, Pak also met a group of people who were on their way to serve their military duty: "They were on donkeys, looking ragged and tired," he wrote. "I realized that [the Chosonn boundary control] is more reliable whereas China's is very lax." ${ }^{22}$ The strict regulations that the emperor issued in Beijing were seemingly failing to reach the empire's margins.

After passing through the vacant land, the Chosŏn embassy reached the Fenghuangcheng office. A Korean interpreter was sent ahead to the gate to report the arrival of the embassy, so the Fenghuangcheng senior commandant received the Korean visitors at the gate. Qing officials also checked the number of people in the embassy and the amount of luggage they had with them against the delivered documents. Any Koreans whose names were not listed were prohibited from passing through the gate. ${ }^{23}$ However, there were numerous opportunities to evade this inspection. In 1806, for example, the Fenghuangcheng office allowed a given 
number of Koreans to come to the gate from Uiju in order to provide food and other necessities for the Chosonn embassy. Despite the Qing court's warning to the Koreans not to abuse this opportunity to cross the river, Korean merchants considered it official permission to visit the Qing gate for trading. ${ }^{24}$

Dealing with the corruption of local Qing officials was an expected part of passing through the Fenghuangcheng gate. When the Korean embassy brought their tribute and luggage to the gate, its members usually presented a certain quantity of gifts to the Fenghuangcheng office. But these offerings eventually became a required "entrance fee" that grew every year as the Qing officials increased their demands. The exchange of "gifts" at the gate often developed into a fistfight between Korean interpreters and Qing soldiers and porters. ${ }^{25}$ The abuses by the Fenghuangcheng officials grew more and more egregious, to the point that in 1811 court officials in Beijing formally accused them of having received Korean bribes for entry through the gate. ${ }^{26}$ Two years later, Fenghuangcheng officials were criticized again for exacting bribes and entrance fees from the Koreans. ${ }^{27}$ Korean aspirations to enter China caused the rampant corruption of Qing officials at the crossing point; but on the other hand, this corruption also made it possible for numerous unauthorized Koreans to continue to cross into Qing territory.

\section{TRADING OPPORTUNITIES}

Koreans participating in tribute missions were given an official right to do business during their journey to Beijing. During the Qing period, Korean embassies were officially permitted to carry up to eighty kŭn (C. jin) of ginseng, or the equivalent value in silver or other goods. A bundle (K. pó) contained ten kŭn of ginseng, so the total trading allowance equaled eight bundles (K. palp'o). Later, the term palp'o came to stand specifically for the Chosonn embassies' right to trade in China. ${ }^{28}$ The palp'o trading right was granted to embassy officials, including the chief ambassador, the vice ambassador, the attendant secretary, military guards, and interpreters. It held more importance for interpreters than it did for high officials, because the former regarded the palp'o trading right as a substitute for their salaries, while the latter thought of it more as a bonus for serving the court.

Chinese silk was the main item that Korean merchants wanted to purchase when they visited the Qing empire. The Korean love for Chinese silk is described well in the stories of Zheng Shitai, a Beijing merchant who supplied Koreans with silk fabrics from Jiangsu and Zhejiang Provinces. Every year he ordered Chinese silk products worth as much as one hundred thousand liang of silver, all intended for his Korean customers. If the silk Zheng had ordered did not arrive in time, the Chosŏn embassy would actually postpone its departure from Beijing. ${ }^{29}$ Winter hats made in Zhonghousuo, a town near Shanhaiguan, were among the other Chinese commodities that were popular with the Koreans. Hong Taeyong (1731-1783) 
TABLE 2 The size of the p'alp'o trade.

\begin{tabular}{|c|c|c|c|}
\hline & $\begin{array}{l}\text { Rank } \\
\text { (number of individuals) }\end{array}$ & $\begin{array}{l}\text { Silver allowed per } \\
\text { person (liang) }\end{array}$ & $\begin{array}{l}\text { Total amount of } \\
\text { silver (liang) }\end{array}$ \\
\hline \multirow{4}{*}{ High officials } & Chief ambassador (1) & 3,000 & 3,000 \\
\hline & Vice ambassador (1) & 3,000 & 3,000 \\
\hline & Attendant secretary (1) & 2,000 & 2,000 \\
\hline & Military guards (7) & 2,000 & 14,000 \\
\hline Subtotals & $(10) \quad-\quad-$ & $-\quad-$ & $22, \overline{000}$ \\
\hline \multirow{9}{*}{$\begin{array}{l}\text { Interpreters } \\
\text { (temporary } \\
\text { positions) }\end{array}$} & Chief interpreters (2) & 3,000 & 6,000 \\
\hline & High interpreters (2) & 2,000 & 4,000 \\
\hline & Official for questions (1) & 2,000 & 2,000 \\
\hline & Officials for local products (8) & 2,000 & 16,000 \\
\hline & Officials for annual tributes (3) & 2,000 & 6,000 \\
\hline & Officials for food (2) & 2,000 & 4,000 \\
\hline & Manchu interpreter (1) & 2,000 & 2,000 \\
\hline & Assistant interpreter (1) & 2,000 & 2,000 \\
\hline & Ǔiju military officials (2) & 2,000 & 4,000 \\
\hline Subtotals & $(22)-\square \quad-$ & $-\quad-$ & 46,000 \\
\hline \multirow{3}{*}{$\begin{array}{l}\text { Minor officials } \\
\text { (temporary } \\
\text { positions) }\end{array}$} & Physician (1) & 2,000 & 2,000 \\
\hline & Writer (1) & 2,000 & 2,000 \\
\hline & Painter (1) & 2,000 & 2,000 \\
\hline Subtotals & (3) & & 6,000 \\
\hline Total & $(35)$ & & 74,000 \\
\hline
\end{tabular}

SOURCE: Yu and Yi, Chosŏn hugi Chungguk kwa ŭi muyŏksa, 57.

visited hat shops in Zhonghousuo and declared, "All of our Korean hats come from here." ${ }^{\circ}$ Fifteen years later, Pak Chiwŏn confirmed that Koreans still purchased huge numbers of Chinese winter hats made in Zhonghousuo, adding, "If you calculate the amount of silver we bring to China on these winter solstice embassies [and other official missions] . . . it is no less than one hundred thousand liang of silver. In ten years the total comes to one million liang." ${ }^{31}$ Silver was the currency most commonly used to buy Chinese products, but the Koreans also traded other items, such as paper, fans, hides, cotton fabrics, and furs. Besides silk, Korean visitors also purchased cotton, dyes, pepper, fruit, and pottery; most of these purchases they made at the Fenghuangcheng gate. ${ }^{32}$

Various opportunities for trading were available to the Chosŏn embassy between the Yalu River and the Fenghuangcheng gate. ${ }^{33}$ From Uiju to the Fenghuangcheng gate, the embassy had to manage the transportation of the tribute and other luggage by itself. This seemingly inconvenient situation in fact provided the Korean merchants with a huge business opportunity. The Üiju office often sent extra horses to accompany the envoy in case of unexpected incidents during the 
journey, and these spare horses did not go to the Fenghuangcheng gate with empty carts. Korean merchants used them to carry their own commodities to trade with the local Chinese at the gate. The number of spare horses increased steadily, along with the frequency of this type of private trade. Officially, merchants were allowed to bring only a dozen horses, but a Chosŏn court official noted in 1686, "In these days private merchants and officials in the embassy take as many as one thousand horses." 34

The area beyond the Fenghuangcheng gate on the way to Shengjing also provided the Koreans with plentiful opportunities for trade. Once the Chosŏn tribute was delivered to Shengjing, it was managed by Qing officials and soldiers. After the goods were handed over, a Chosŏn official with the title of military escort (K. tallyŏnsa) returned to Üiju with the part of the embassy that was not traveling on to Beijing. On his way back, he often used the horses, now relieved of their burdens, to carry the commodities he had acquired in Shengjing. Before 1705, the tallyŏnsa was selected from among the military officers in Ǔiju, but subsequently a merchant was appointed to the position. By the time the tallyŏnsa left Shengjing and returned to Ǔiju, he had often made too many purchases to carry in his own carts. He then hired local Qing people to deliver his goods to the Fenghuangcheng gate, where Koreans from Ǔiju were waiting to receive him. Those who came to meet the tallyonsa at the gate themselves never arrived empty-handed; they also did not want to miss the chance to trade Korean commodities with local people in Fenghuangcheng. ${ }^{35}$

These systemic appropriations by Korean merchants of the horses and services provided for the tribute embassy transformed the Qing gate into an active marketplace. Korean interpreters described the situation at the gate around 1715 as follows:

In the past ten years, the city [of Fenghuangcheng] has grown, as the market developed and more people moved in. When the market opened, the city was full of carts and horses, carrying cotton from Jinzhou, Fuzhou, Haizhou, and Gaizhou; cotton fabrics from Shenyang and Shandong; and hats from Zhonghousuo and Liaoyang. Ships from the south [China] also came to the harbor of Niuzhuang. Beijing merchants came to the Fenghuangcheng gate with silk and other commodities. The shops on the streets looked like those in any city inside Shanhaiguan. The clothes and accessories worn by the merchants [at the Fenghuangcheng gate] were as splendid and lavish as those of high officials. ${ }^{36}$

In order to prolong the time available for conducting business in Fenghuangcheng, embassy interpreters often cooperated with private merchants and delayed the embassy's departure from the gate to the Yalu River. Korean officials complained about the widespread smuggling and hectic trade at the Fenghuangcheng gate:

On their way back to the Chosŏn, officials in the embassy often hurry to leave and cross the Yalu River. These officials do not want to wait for [their servants who have 


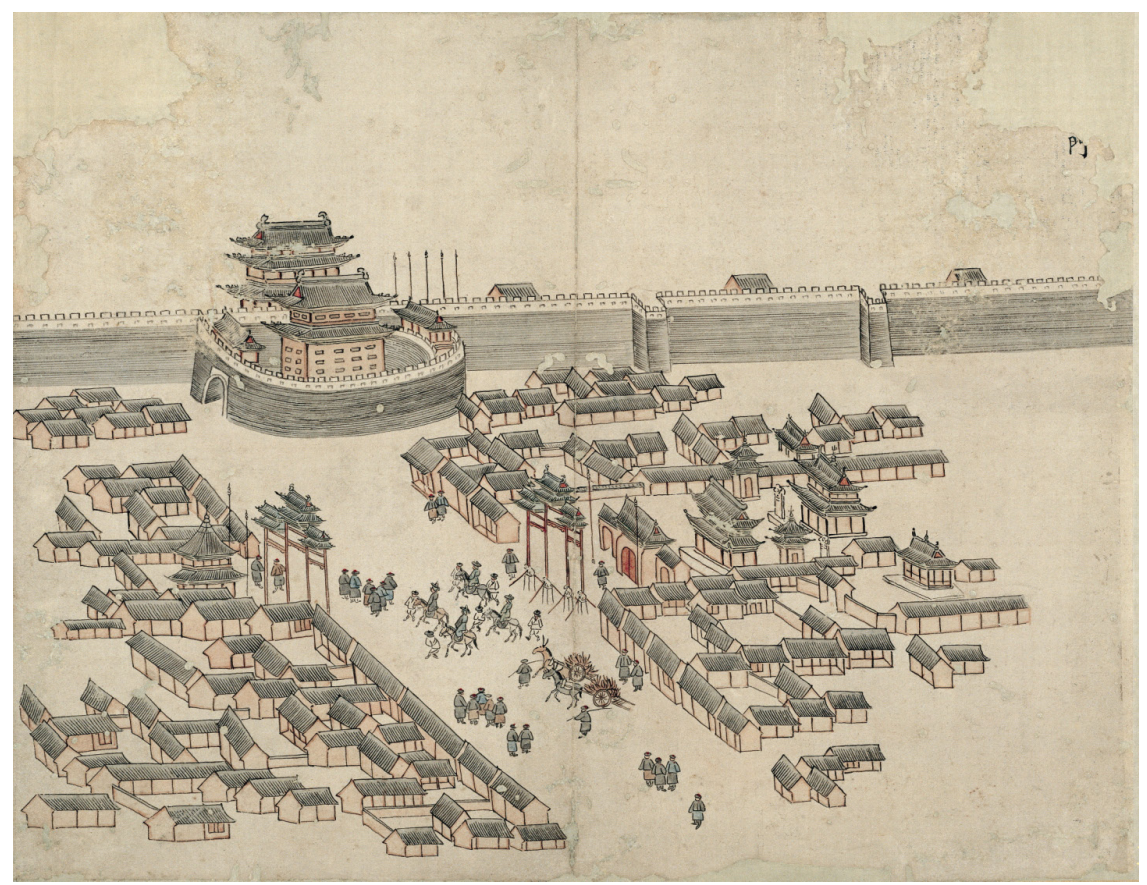

FIGURE 10. Choyangmun (Gate of Rising Sun), circa 1784. Hand scroll, ink and color on paper, $35.4 \times 45.3 \mathrm{~cm}$. From Yǒnhaengdo: Paintings of the Korean Envoys to Beijing during the Joseon Dynasty (Seoul: Sungsil taehakkyo Hanguk Kidokkyo Pangmulgwan, 2009), 14. Used with permission.

to move slowly to transport] the imperial gifts for the king, so they are the first ones to cross the Yalu River. They eventually leave behind [at the Fenghuangcheng gate] interpreters and retainers from the embassy, who are free to go back and forth between the gate and Ǔiju. They are given a lot of time to trade with Qing people. ${ }^{37}$

The departure of the high officials gave the rest of the embassy free rein to conduct trade. In this way, the Qing-Chosŏn tributary relations made their boundary wide open to Korean merchants.

\section{THE TRANSPORTATION BUSINESS}

If the Korean traders were mostly interpreters and Ǔiju merchants, their Qing counterparts were local merchants in Fenghuangcheng and Shengjing. The best opportunity for local people to work with the Koreans was in helping to transport the Chosŏn embassy's huge amount of baggage - the tribute for the Qing emperor and food and necessities for the embassy itself-across the Yalu River, through 
Fenghuangcheng, and on to Shengjing. The local porters were mainly villagers who lived along the road between Fenghuangcheng and Shengjing, a route that included eight postal stations in the Shengjing region, which were known as the "eight eastern stations" (Dong bazhan)..$^{38}$ Upon arrival in Shengjing, the Chosŏn tribute was handed over to the Shengjing Board of Revenue; a portion of it was left in Shengjing, and the rest was taken on to the imperial court in Beijing. The transport and care of the tribute now became the responsibility of Qing officials. ${ }^{39}$ The Chosonn tribute was not the only item to be delivered. The Korean visitors often wished to travel more comfortably, so they employed local people to drive them in horse-drawn carriages to Shengjing or even all the way to Beijing. By the nineteenth century, it was so common for members of the Korean embassy, even interpreters and traders, to rent carriages in Fenghuangcheng that "riding on a horse became a matter of shame." ${ }^{40}$

For the local people living in this remote margin of the Qing realm, the business of providing transportation for the Korean embassy presented an infrequent but very profitable opportunity. The transport business soon became an important part of the local economy. As a Korean visitor pointed out, "Local people [at the eight stations] were entirely dependent for their living on transportation of Korean luggage." ${ }^{41}$ In 1660, a Korean traveler noticed that it was easier and cheaper to hire local porters in the winter, when they were not working in the fields. ${ }^{42}$ By the late seventeenth century, wages for transportation were standardized: "It costs five liang of silver to have a piece of luggage carried from Fenghuangcheng [to Shengjing]. The same trip in the other direction was twice as expensive... People from the eight stations make huge profits, so the streets are full of lavish houses." If a cart could carry several pieces of luggage at once, the wages that local porters earned were indeed substantial. ${ }^{43}$ Pak Chiwŏn also recognized the economic benefits that Qing locals accrued from the Korean embassies. When he asked people living near the Fenghuangcheng gate about their livelihoods, he was told, "Our lives would be threatened without the visits from your country." 44

The lucrative business of luggage transportation for the Chosonn embassy soon attracted the attention of the Shengjing merchants, who in the late seventeenth century organized a group called the lantou to monopolize the Korean trade: "From 1689 onward, a local man in Liaodong named Hu Jiapei organized a transportation cartel called the lantou. Hu and other merchants took exclusive charge of carrying the luggage [of the Chosŏn embassies]" "45 These merchants were so rich that they were believed to "have a thousand slaves and keep numerous mistresses." Most importantly, they had a close relationship with Qing officials in the Shengjing Boards of Rites and Revenue. Seven of the twelve lantou merchants were, in fact, Shengjing officials. Therefore, even before the granting of official approval for the lantou business, the Shengjing office informed the Korean embassy that their luggage should be handled by the lantou merchants. ${ }^{46}$ 
The lantou cartel, operating under the protection of the Shengjing office, exploited the Chosŏn embassies. First, the lantou merchants intervened in the scheduling of the Chosŏn embassy's departure and dates of stay, so that the embassy often had to stay in Qing territory for several additional months, wasting funds and causing perishable goods to spoil. Second, the Qing merchants often provided poor service; for example, in 1690, when the Fenghuangcheng senior commandant came to the gate to receive the Chosŏn embassy, the lantou merchants, blaming the rain, did not show up to take the embassy's luggage. Without lantou transportation, the members of the Chosŏn embassy had to sleep in their carts in the rain. ${ }^{47}$ Korean discontent with the lantou monopoly is well documented in Chosŏn records:

Once the Chinese lantou merchants began to monopolize transportation, the delivery fee doubled. These greedy Chinese merchants volunteer to pay taxes to the Shengjing office and cooperate with the officials there, and in return they monopolize the benefits from the Korean trade. At the Qing gate, they intentionally delay the departure of the embassy [to Üiju] or tell the [Chosŏn] officials to return to Korea first, and then they trade freely [with the merchants]. ${ }^{48}$

The lantou merchants developed a special connection with the Korean interpreters, who helped increase the former's influence over the Chosŏn embassies. When the Koreans arrived in Fenghuangcheng, the lantou held a lavish reception banquet to entertain the foreign visitors. ${ }^{49}$ On the way back to Ǔiju, the attendant secretary and minor officials in charge of the luggage were invited to stay an extravagant house owned by the lantou merchants. ${ }^{50}$ It was arguably the Korean interpreters who monitored an embassy and provided information about it to the lantou merchants. One Korean official cynically noted, "There are fourteen lantou merchants," referring to the twelve Qing merchants plus the two embassy interpreters covertly collaborating with them..$^{51}$

The monopoly of the lantou cartel was not favorable for Korean traders. When some of the Korean merchants purchased illegal commodities in Shengjing and were caught in the inspection in Fenghuangcheng, the lantou used this opportunity to curb Korean merchants from making transactions without its approval. The lantou merchants manipulated the Fenghuangcheng officials into complaining to the Chosŏn court about illegal Korean trade, an accusation that led to the dismissal of the Üiju magistrate on charges of neglecting the inspections at the Yalu River. ${ }^{2}$ This incident demonstrates the influence of the lantou merchants: their power reached the Chosŏn court and affected Chosŏn inspections at the Yalu River.

The lantou cartel also exploited local Qing people at the eight eastern stations. While the lantou merchants charged the Korean embassy ten liang of silver for delivering a cart to Liaoyang, they paid local porters only two and a half liang and kept the remaining seven and a half liang for themselves. In 1712 the local people 


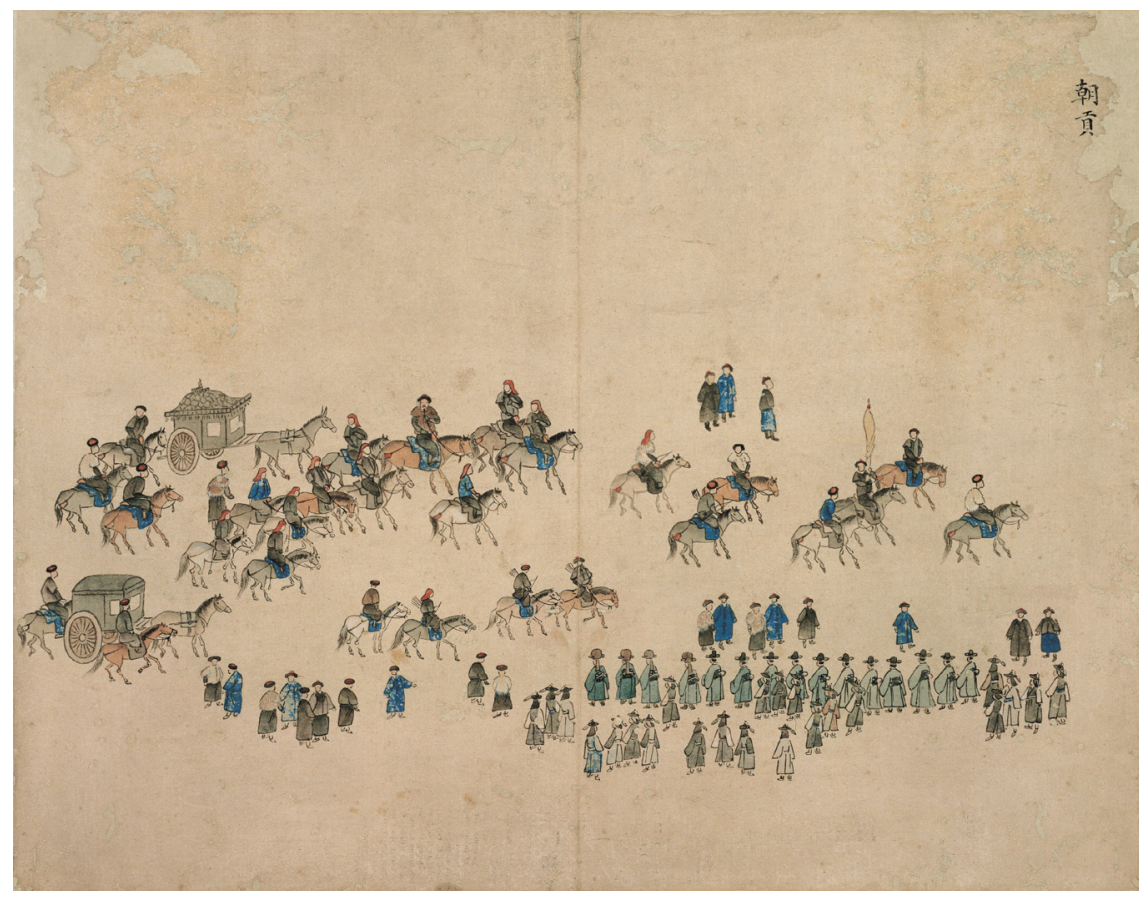

FIGURE 11. Chogong (tributary ritual), circa 1784. Hand scroll, ink and color on paper, $35.4 \times$ $45.3 \mathrm{~cm}$. From Yornhaengdo: Paintings of the Korean Envoys to Beijing during the Joseon Dynasty (Seoul: Sungsil taehakkyo Hanguk Kidokkyo Pangmulgwan, 2009), 16. Used with permission.

sought to reclaim the profits from business with the Koreans by taking legal action against the lantou impositions. ${ }^{53}$ In response to this litigation, and with the intent to protect their cartel, the lantou merchants bribed the Manchu officials in Shengjing, who eventually wrote a memorial to the Kangxi emperor requesting that the lantou organization be protected rather than abolished. The money for the bribe, surprisingly, came from the Chosŏn embassy. ${ }^{54}$ In the end, the lantou won the lawsuit and maintained its monopoly over the provision of transportation services to the Korean embassy.

Continuing abuses by the lantou merchants finally led the Chosŏn king, Kyŏngjong (r. 1720-24), to ask the Yongzheng emperor to abolish the cartel. Soon the Qing and Chosŏn courts launched a joint investigation of $\mathrm{Hu}$ Jiapei and other lantou merchants in Fenghuangcheng. In 1723, Hu was finally deprived of his monopolistic right to the Korean trade and made to wear a cangue for three months after receiving one hundred lashes from a flogging leather (bian). Not only were the lantou merchants punished, but the Fenghuangcheng senior commandant was also disciplined for corruption and abuse of power. After the lantou cartel 
was dismantled, the Korean embassy was once again free to hire carts and horsemen directly from the local Qing population. ${ }^{55}$ However, the breakup of the lantou did not come without a cost. Since the Shengjing and Fenghuangcheng offices lost two thousand liang of tax income and other benefits that they had received from the lantou merchants, the Qing officials turned to the Koreans with their grievances. To appease them, the Korean embassy agreed to hire only local porters recommended by the Fenghuangcheng officials. ${ }^{56}$

\section{"DISHONORING THE STATE”}

As early as 1700, it was known that some Koreans associated with the Chosorn embassy were indebted to Qing merchants. Well aware that such a situation might cause further problems, the Chosŏn court ordered the decapitation of any Korean trader owing money to Qing subjects, regardless of the value of the debt.57 However, even this harsh ruling failed to end credit transactions between Qing and Chosŏn merchants. Trading on credit became an issue again in 1706, when Qing merchants in Fenghuangcheng made an official complaint about Korean liabilities. ${ }^{58}$ The following year, the Chosŏn court sent the accused debtors to Fenghuangcheng for interrogation, which revealed that only one out of the nine accused Koreans had actually borrowed any money. The rest were being falsely accused: the contracts with the accused Koreans had been forged and signed by the Qing accusers themselves. The Fenghuangcheng senior commandant, evidently backing his countrymen, told the Chosonn officials that he was interested only in receiving the money owed and was not concerned with the fate of the debtors. ${ }^{59}$

It was in 1724, soon after the dissolution of the lantou cartel, that the enduring credit practices finally caused serious diplomatic tensions between the Qing and Chosŏn courts. In that year, the Shengjing officials found that Hu Jiapei and his eleven cosigners, the former lantou merchants, owed a substantial amount of money to the Shenging office. ${ }^{60}$ The money, which the lantou merchants had borrowed from the office over more than seventeen years, was now tied up in huge outstanding loans to numerous people, including thirty-eight officials in the Shengjing office and eighteen in the Imperial Household Department in Beijing. The greatest debtors, however, were Korean traders. There were 247 Korean debtors who together owed more than sixty thousand liang of silver. ${ }^{61}$

The Shengjing office reported the staggering Korean debts to the Yongzheng emperor, who eventually ordered the Chosŏn court to investigate the issue and to repay the money. However, the emperor's order to cross-examine the Qing accusers and the Chosonn accused at Zhongjiang on the Yalu River was nearly impossible to follow. One of the problems was that there was no way to locate the hundreds of Korean traders who frequently changed their names and constantly moved back and forth across the Yalu River. Beyond the issue of locating 
the debtors, the Chosŏn court also had no intention of spending more than sixty thousand liang to pay off private debts. Clearing these debts on behalf of private traders would have set a precedent that would have opened the door for similar claims by the Qing in the future. After long discussions, the Chosŏn court decided to explain to the Shengjing office that the Korean debtors should, indeed, be decapitated on the shore of the Yalu River but that their private debts would not be taken care of by the state. ${ }^{62}$ As a result of the Chosŏn court's repeated petitions, the Yongzheng emperor finally decided to dismiss the case of Korean debts to Qing merchants in 1728 :

The late Chosŏn king [Sukchong] was praised by the Kangxi emperor for his capability and modesty. He enforced the law properly to punish Korean debtors and acted fairly. I have heard that the present king [Yŏngjo] is weak and incompetent.... An investigation of debtors would be beyond his capacity. Ordering [the Chosŏn king] to undertake an impossible task is not appropriate to my intent to embrace foreigners. Therefore, it is not necessary to interrogate the criminals. I am generously waiving the silver that the Chosŏn subjects are supposed to pay. This decision is meant to bestow a favor on a foreign subordinate [waifan], not to ease regulations on foreigners to a greater extent than is the case for people in the inner land [neidi]. ${ }^{63}$

In referring to the Chosŏn king as weak and incompetent, this imperial letter was surely insulting to the Koreans. After the embarrassing incident of "falling into debt to the Qing and dishonoring the state" (K. Chŏngchiae yokkuk), ${ }^{64}$ the Chosŏn court tried to implement rules limiting Korean trade with Qing merchants. Upset with the accusations made by the Yongzheng emperor, the Chosŏn king Yŏngjo blamed the credit problem on rampant trade activities. His court officials agreed that it was the private merchants sneaking along with the embassy to Shengjing who were causing all the trouble. The Chosŏn court was convinced that as long as merchants continued to join the tributary embassy traveling to Shengjing, humiliating problems such as financial obligations to Qing merchants would persist. ${ }^{65}$ Finally, the court decided to authorize trade in Shengjing only for the embassy's interpreters. Soon thereafter, other types of trade, such as using extra horses at the Fenghuangcheng gate and joining the Korean tallyŏnsa group in Shengjing, were also prohibited. Yŏngjo ordered that the local Qing porters should deliver the tribute and the luggage from Fenghuangcheng all the way to Shengjing, an edict intended to eliminate any opportunity for Korean merchants to enter the gate and to reach Shengjing. ${ }^{66}$ In short, the Chosŏn court sought to end debt problems by closing off all possibilities of trade for the tribute embassy between Fenghuangcheng and Shengjing.

However, these attempts were ineffectual, because the Korean trade with the Qing was already inextricably linked to the maintenance of the Chosŏn tribute embassy visits. In fact, the embassy needed a vast amount of silver in addition to the money required to prepare the tribute and gifts for the Qing emperor. 
Whenever the Chosŏn embassy handed over the tribute, delivered documents, collected information, or discussed complicated issues with Qing officials in Beijing, the delegates had to present gifts or silver. It was the profits from the trade along the embassy's journey that made the tribute mission possible; the practice of the embassy visits would have been impossible without the substantial amount of silver gained from trade with Qing merchants. In other words, the trade and the tribute embassy existed in a symbiotic relationship, neither being possible without the other. Therefore, the growth of the trade with the Qing was a top priority for the Chosŏn tribute embassy, and abuses by merchants, such as shady credit practices, needed to be tolerated. As a result, Yŏngjo's efforts to regulate the Chosŏn embassy's trade were doomed to fail. Before long, smuggling was rampant from Ǔiju to the Fenghuangcheng gate and on to Shengjing, and silver continued to cross the Yalu River. Finally, in 1754, the Chosŏn court had to reauthorize trade with the Qing for Üiju merchants who served the tribute embassy. ${ }^{67}$

The markets in Fenghuangcheng and Shengjing continued to thrive during the eighteenth century. In 1780, Pak Chiwŏn reported that numerous Qing subjects waiting for the arrival of the Korean embassy at the Fenghuangcheng gate were pleased to meet the Korean interpreters and other retainers, who were in fact all merchants from Ǔiju. The two groups were familiar with each other thanks to the regular visits of the Chosŏn embassy. When Pak and his friend stopped by a civilian's house in Fenghuangcheng, they found it full of Korean packhorse drivers and servants having drinks. ${ }^{68}$ From this point onward, all of the Korean luggage was to be carried on carts belonging to the local people, as King Yŏngjo had earlier ordered; this did not, however, stop Korean trade with the Qing, as the king had hoped. Instead, Korean visitors continued to bring their goods for trade to Fenghuangcheng.

The local Qing population actively contributed to the creation of a meeting place with the Koreans. Throughout the eighteenth century, Korean embassies continued to rely on local cart drivers for the transportation of their luggage. The end of the lantou monopoly did not ease the problems of carrying luggage to Beijing via Shengjing. In 1790, when the Chosŏn embassy had to rush to leave Shengjing in order to celebrate the Qianlong emperor's eightieth birthday in Beijing, Qing cart owners attempted to take advantage of the situation by raising cart fees to ten times their normal level. The accompanying Qing officials recognized the attempted exploitation and punished the cart owners, forcing them to lower their fees. Indignant at this decision, the owners responded by causing further trouble for the Korean embassy by hiring local gangsters to drive their carts. The leader of the cart drivers, who called himself a bannerman of the Plain Yellow Banner, frequently delayed the departure of the embassy by demanding "a break after every five $l i$ and a drink after every ten $l i$." The Koreans were annoyed but could do nothing since 
they were dependent on the local people for their journey. ${ }^{69}$ Chosŏn tribute paying and Qing profit seeking were inextricably intertwined to create a flourishing trade in goods and services in the Shengjing region.

\section{THE ISSUE OF SILVER THEFT}

Although it was the emperor sitting in Beijing who received the Chosonn embassies and their tributes, it was the Shengjing military governor who had to deal with all practical matters related to the Korean visitors. A variety of Chosŏn affairs, ranging from control of illegal trade to the resolution of liabilities among merchants and the prevention of trespassing, fell under the auspices of the Shenging office. Accordingly, when the Chosonn embassy reported that some of its belongings had been stolen, the Shengjing military governor managed to connect the incident to the earlier arrest of ginseng poachers in an entirely different location in order to shape the implementation of the Qing Chosŏn policy. The military governor in question was Daldangga, who had failed to gain the emperor's permission to build a military guard post at the Yalu River in 1746. As discussed in chapter 3, Daldangga had sought to combat the problem of ginseng poaching by strengthening the Qing military presence in the area near the boundary, but his plan was thwarted by strong opposition from the Choson court, which persuaded the emperor to veto the idea. It was less than a year after the frustration of the denied guard post proposal that Daldangga was informed of a Korean packhorse driver who had lost his silver near Liaoyang. The military governor, surely annoyed by the Chosonn court, saw a good chance to exact revenge for the failure of his security plan.

The case of Sahwan and Song Erdazi, described at the beginning of this chapter, reached Daldangga after passing through several hands: first the village head of Wanbaoqiao, then the Liaoyang senior commandant, and finally the Fengtian prefect. The village head said that Song Erdazi, the man accused of stealing the silver of the Korean Sahwan, had been tricked into opening his door to the Koreans, and that his good intentions to help the foreign travelers had unexpectedly been met with assault. Song Erdazi recounted the ensuing situation in detail:

Wu Er and Zhang Lian, who were staying in my house at the time, were also tied up and sent to the [local] office. ... [The Koreans insisted] that their silver had been found in the pile of sorghum in my house and tied me up again. They did not even give us time to put hats on our heads or socks on our feet. . . My house is located very close to the main street. Since they had hurried to catch up with me and soon reached me in front of my place, how could I have managed to remove a package of silver from the horse and hide it in the sorghum pile? ${ }^{70}$

According to the village head's report, the two individuals, Wu Er and Zhang Lian, who were working for Song at the time and staying at his place, had not put on 
proper clothes, hats, or socks before they were taken to the local office-evidence implying that they had been mistreated during the arrest. ${ }^{71}$ One of Song's neighbors also reported that the Koreans had attacked him after he heard a scream and ran to Song's place: "The Koreans asked who I was. I said I was [Song's] neighbor. Then a Korean came with a bamboo stick and hit me on the head twice. My head was torn up. I was so scared that I ran back home." Later he showed his scar to a local official as evidence of the assault. ${ }^{72}$

Song Erdazi, Wu Er, and Zhang Lian were all residents of the area near the tribute route who had presumably been hired to transport the Koreans' luggage. What is striking in the accounts of this case is the apparent attitude of the Korean travelers toward the local porters who provided transportation services for them. Under the excuse of searching for the lost silver, the Koreans moved around in an intimidating crowd, forced their way into houses, searched through them, and attacked locals at will. It was these Korean foreigners, not Qing soldiers, who found the suspects, tied them up, and sent them to the office. It is true that there were only a dozen Qing soldiers accompanying the tribute embassy-too few to properly escort hundreds of Koreans-so the Koreans had to protect themselves. However, the primary reason why the Koreans felt able to act in such an arrogant way in the territory of the "superior country" was that they were at a remote margin of the empire, where Koreans appeared with regularity. In addition, the economic relationship between the Korean embassy and the local Qing population was that of employer and employee, another factor that emboldened the Koreans to behave imperiously, or even abusively, in this context. Furthermore, Korean interpreters forwarded Sahwan's allegation directly to the Shengjing Board of Rites, and Qing soldiers imprisoned Song Erdazi solely on the basis of the Korean servant's accusation without further investigation. All of these facts indicate that the Koreans were uniquely privileged in this remote region.

However, Daldangga had no intention of protecting the privileges Koreans enjoyed within his jurisdiction. The fact that Sahwan's testimony contradicted that of Song Erdazi raised his suspicions, so he decided to summon the suspects and to conduct his own questioning. Song Erdazi, Wu Er, and Zhang Lian were pressured to tell the truth with the threat of severe treatment if they failed to do so, but they continued to insist that they had not stolen any silver from the Koreans. ${ }^{73}$ On the other hand, all of the Korean interpreters and Qing soldiers questioned by Daldangga answered that they had not themselves seen when and how Sahwan lost the silver, and that they had relied on his word only in reporting the theft. It also turned out that not one of the other Korean packhorse drivers had seen exactly how Sahwan lost his silver. ${ }^{74}$

Convinced that Sahwan held the key to resolving the affair, Daldangga called him back for further questioning. Daldangga asked Sahwan why he had changed his testimony concerning what he saw in front of Song Erdazis house, why the 
other packhorse drivers had not seen the "man on horseback" he had mentioned, and whether he acted with violence while tying up the suspects. Surprisingly, Sahwan confessed that his testimony had been a lie:

As it was getting dark, it became very windy. We arrived near Wanbaoqiao around the time of the rooster's crow. Desiring to smoke, I slackened the reins of my horse and struck a light. Not expecting it, my horse was so startled by the light that it ran away. I followed the sound of the hooves to the west, arriving in front of Song Erdazi's house. When I grabbed my horse, I found that one of the two bundles of silver had fallen to the ground, but the other one was gone. I was so scared that I began to cry. Then many of my colleagues joined me. I tried to light up the area to search for the silver bundle, but Song Erdazi would not give me a light. When I said I was lost, he opened the door. When I said I had lost some silver, he said he did not know anything about it. Then I said, "My horse was standing in front of your house and the silver was gone. If you did not take it, then who could have taken it?" My colleagues came to tie him up. . . . Later, I found the other silver bundle on the ground. By then people had already tied [Song and the others] up. If I had confessed that it was actually me who had scared the horse, causing it to run away and drop the silver on the ground, my lord would have blamed me not only for being reckless but also for falsely accusing innocent people. I was so scared that I lied about finding the silver in the pile of sorghum. ${ }^{75}$

After revealing that Sahwan had lost the silver himself and then falsely accused innocent locals of a crime, Daldangga sent all of the Koreans involved back to Korea, asking the Chosŏn king to resolve the case. He also proposed punishments for each of them. Sahwan had committed two crimes, namely, the fabrication of the theft of silver and the false accusation of an innocent party, so Daldangga suggested that he be beaten sixty times by a heavy flogging stick (zhang) and sentenced to penal servitude $(t u)$ for a year. He recommended that Sahwan's lord, Yun Changli, also be punished for blindly trusting his servant's word and falsely accusing innocent Qing subjects. According to Daldangga, the Korean interpreters were all guilty, too, because they had not conducted an appropriate investigation of the incident, but merely reported that a Korean servant's silver had been stolen. Finally, he declared that the Qing soldiers were not innocent either: they should be punished for having neglected to investigate the theft carefully and to report it immediately to their superior, in addition to having failed to provide the foreign embassy with proper escort service.

Daldangga suggested that the Chosŏn king deal with the Koreans involved in the case: "This incident happened because people from the small country are ignorant of what is right and wrong. I beg the emperor to show generous forgiveness and great kindness in allowing the Chosŏn king to punish the people concerned." ${ }^{6}$ However, this seemingly generous offer to let Koreans discipline Koreans offered no comfort to the Chosŏn court. The Chosŏn officials took offense at the edict 
from the Qing Board of Rites, which blamed Yŏngjo for neglecting his duties.77 Some court officials argued that in addition to the individuals involved in the false accusation of theft, the delegate who brought such an odious letter to the Chosorn court should be punished. ${ }^{8}$ In addition, the Chosŏn court distrusted Daldangga's intentions in the case. The Koreans believed that there were more pressing issues than the Sahwan case affecting the Qing-Chosŏn relationship, most notably the increasing number of illegal Qing settlers in the area near the Yalu River. ${ }^{79}$ They suspected that Daldangga had attempted to take advantage of the Sahwan case to deflect attention from the problem of illegal settlers at the boundary-a phenomenon that, in the view of the Chosonn, had far greater potential to damage the QingChosŏn relationship in the long run. "The Qing authorities, especially Daldangga, are not trustworthy," was a common view among Chosŏn court officials discussing the sentences of Sahwan and the others concerned in the case.

\section{BROADENING THE INVESTIGATION}

The Koreans may have expected the incident of Sahwan's false accusation to end with the ruling that Sahwan and Yun Changli be sent into exile. However, Daldangga had different plans. Prompted by the shocking realization that Koreans had dared to level false accusations against Qing subjects in Qing territory, the Shengjing military governor decided to reinvestigate similar cases that had happened earlier. Daldangga wrote a letter to the Qianlong emperor, describing two other cases akin to Sahwan's. According to his investigations, Sahwan was not the only Korean to have reported a loss of silver in Qing territory. One case had occurred in 1744, when a group of Koreans had passed near Langzishan and one of them, Yi Goroja, had reportedly discovered his silver missing and accused a local innkeeper of the theft. The case had not been resolved, Daldangga explained, because the suspected innkeeper had since died of an illness and Yi Goroja had returned to Korea without waiting for the results of the investigation. ${ }^{80}$ The second case, involving a Korean interpreter, Yi Yunbang, similarly remained unsolved. This case had happened in 1745, when Yi Yunbang and eleven other members of the Chosŏn embassy had reported their silver missing near Shilihe. Once again, the Koreans had accused an innkeeper, but the thief had not yet been identified. ${ }^{81}$

Having observed the case of Sahwan, Daldangga did not believe that Yi Goroja and Yi Yunbang had really lost silver in Qing territory:

The suspects have already been questioned several times, but they have never changed their original testimonies, bitterly insisting that they are innocent. It is not right at all that we rely only on the word of Koreans and suspect [our subjects] of being criminals. If we ask the Chosŏn king to collect testimony from the accusers, it is very likely that they will simply repeat what they said earlier. This case will not 
be resolved in that way. An attempt to solve this case [based on the statements of Koreans] will end up having the same result as we saw in the case of Sahwan, who falsely accused Song Erdazi. Without cross-examination of Sahwan and Song Erdazi, the Korean servant would never have confessed the truth, and Yun Changli would never have accepted responsibility for his crime. ${ }^{82}$

In order to figure out who was telling the truth, Daldangga insisted, cross-examination of the accusers and the accused was necessary: "The original testimonies of Yi Goroja and Yi Yunbang are confused and unreliable, so we need to wait for the truth. The suspects consistently claim their innocence, but their statements are also one-sided and should be double-checked against those of the accusers." ${ }^{3}$ The Qianlong emperor endorsed Daldangga's suggestion, and the Shengjing Board of Rites asked the Chosŏn court to immediately send all concerned parties to Daldangga for interrogation. ${ }^{84}$

In the first instance, the Chosŏn court blamed Yi Yunbang and the Korean interpreters for these disputes, which it saw as arising from their careless accusations against Qing subjects without proper evidence. Nonetheless, the Chosŏn court also suspected Qing officials of greed and of seeking bribes from the Korean embassy; the court feared that the upcoming investigation of the previous cases of the Chosŏn embassy's lost silver would trigger even more demands from Qing officials. ${ }^{85}$ In contrast to the Shengjing military governor, who thought that the Koreans, having carelessly lost their silver, had pinned the blame on innocent Qing subjects and managed to avoid the ensuing crises, the Chosŏn court considered all these troubles to have been caused by the corruption of Qing officials. In the end, the Chosŏn court consented to the Qing request on the condition that a Chosŏn official would be allowed to accompany the summoned Koreans and to conduct the investigation together with Qing officials. Accordingly, the vice minister of the Chosŏn Board of Punishment (K. hyŏngjo chiamŭi), Kim Sangjŏk, was sent to Fenghuangcheng with the accusers. ${ }^{86}$ King Yŏngjo gave a special message to Kim Sangjŏk: "It is not proper to punish innocent subjects of the superior country." The king advised Kim to do his best to conduct a thorough investigation of the case. ${ }^{87}$

In 1749, Daldangga's successor as Shengjing military governor, Alantai, reported the result of the investigation to the Qianlong emperor. Quoting the two Fenghuangcheng officials who carried out the joint examination with Kim Sangjŏk, Alantai reported that "the Qing subjects singled out as thieves provided evidence to prove their innocence, whereas the accusations of the Koreans were not verified." It turned out that Yi Goroja and his colleagues had quarreled with the innkeeper over the charge for their stay. Later, finding the group's baggage and a hundred liang of silver missing, a Chosŏn interpreter and a Qing soldier immediately arrested five Qing people staying in the inn and handed them over to the office. However, the baggage of the Koreans was later found inside the house along with 
other items, and only some of the silver was not recovered. Yi Yunbang's case was similar. After the early departure of four of the Korean travelers, the remaining eight discovered that their silver was gone. The Qing soldiers beat up and tortured the innkeeper before sending him to the office. The village head later reported that, in spite of several years of effort, he had found no evidence of the innkeeper's involvement in the theft. ${ }^{88}$

Alantai concluded that Yi Goroja and Yi Yunbang had plotted to level false charges of theft against innocent Qing subjects. To make matters worse, in the course of the reinvestigation it was revealed that Yi Yunbang had also attempted in vain to bribe a servant who was a witness of the case. Yi had given twentyfive liang of silver to the servant to give a false witness statement, but the servant subsequently disclosed the bribe to Qing officials. Yi Yunbang's attempted bribery undermined the efforts of Kim Sangjŏk, who had tried to settle the dispute as a representative of the Chosŏn court. The revelation convinced Alantai of the Korean's guilt, and he insisted that "the Chosŏn king should examine the process by which his Korean subjects made schemes [to falsely accuse Qing subjects] and discuss the sentences of these criminals." He also asked the Qianlong emperor to discipline the Qing soldiers who had failed to investigate the cases properly. ${ }^{89}$

In 1749, the Qing Board of Rites sent the Chosŏn court an imperial edict concerning punishments for the Korean criminals:

Those people, including Yi Yunbang and Yi Goroja, arrested and falsely accused innocent people of the inner land [neidi] and also attempted to buy off a servant. Their crimes deserve a sentence of military servitude. However, imperial favor is blessing them, reducing their sentences to one hundred strokes with a heavy flogging stick [zhang] and penal servitude $[t u]$ for three years. The silver used for the bribe should be sealed and sent back to the Chosŏn court. ${ }^{90}$

Three months later, the Chosonn court reported to the Qing Board of Rites that all of the criminals had been punished, including the Chosonn representative, Kim Sangjŏk, who had been sent to Fenghuangcheng for the cross-examination. ${ }^{91} \mathrm{Se}-$ vere punishments were meted out to all concerned, including the servants who had failed to take care of the silver and instead tried to avoid responsibility by accusing someone else, the interpreters who had too readily trusted the word of their servants and made little effort to discover the truth, and the representative of the Chosŏn court who had participated in the joint interrogation. Daldangga thus succeeded in setting a precedent that he hoped would deter future offenses by Koreans as well as enhance the authority of the superior country.

Despite Daldangga's revelation of the Koreans' false accusations in these cases, the Chosŏn embassy's reports of silver thefts in Qing territory were not always fabricated. Another case shows that some Koreans really did have property stolen from them during their journey and that someone had to take responsibility for their compensation. In 1746, the Liaoyang military commander reported that a 
Korean servant, Yi Chansuk, had lost a thousand liang of silver. As in the previous cases, Yi Chansuk seemed to have lost the silver during his journey with the embassy to Beijing and suspected some of the innkeepers and cart drivers with whom he had been in contact. Unlike in the previous cases, however, Qing officials determined that Yi Ch'ansuk's silver truly had been stolen in Qing territory, but they failed to find the real thief. Who, then, should pay back the silver to the Koreans? After two and a half years of discussion, the Shenging Board of Rites reached the conclusion that the Qing merchants who had contracted to transport the Korean embassy's luggage should take responsibility for the compensation:

These merchants were affluent, so they were able to become the merchants [authorized to work with the Chosŏn embassy]. They were entrusted with the valuables of the Korean embassy and received a huge transportation fee. Nonetheless, they failed to care for the commissioned property and thus caused its loss. It is therefore appropriate that these merchants take responsibility for compensating the owners. They should be put in custody until they pay back the entire amount. Their release can be granted only after everything is paid. The money can be reimbursed later when the real criminal is arrested. ${ }^{92}$

In 1750, the Shengjing Board of Rites sent the specified amount of silver to Korea. ${ }^{93}$ The Chosŏn court wrote a letter thanking the Qianlong emperor for his imperial kindness: "The great country has always taken care of the small country. Your Highness is now showing mercy even to a servant and allowing him to recoup his loss even though such a long time has passed. This is all thanks to the great kindness of the great country. This small country cannot hide its joy and gratitude." 94 To the Korean envoys, the local Qing residents on their travel route were merely innkeepers providing lodging for a night, porters transporting their valuables, merchants acting as trading partners, or even thieves eyeing their belongings. To the Chosŏn king, however, the Qing emperor and the Shengjing military governor represented the highest power in the world, authorities to whom he had to regularly pay homage and tribute, who commanded his obedience when they ordered him to arrest his own subjects and send them to the Qing, and whom he even had to thank for punishing his own people. The relations between the Qing and the Chosŏn thus varied greatly depending on whether their encounter took place in Beijing, Shengjing, or a local town on the far reaches of the empire.

Qing foreign policy guaranteed regular visits from the subordinate neighbor for the purpose of paying tribute, and the Chosŏn practice of sending tributary embassies created an opportunity for Koreans to make regular contact with Qing people. The various cases involving members of the Chosŏn embassy on the Fenghuangcheng-Shengjing route demonstrate that the practice of tribute payment, originally intended to preserve the political hierarchy between the Qing and 
Chosŏn courts, also had an unexpected outcome, as a great number of Koreans, along with their money and goods, were attracted first to their boundary and then to the Qing northeastern margin. Korean travelers had to depend on the local Qing population for various services in order to make the journey to Beijing for an audience with the emperor. The tributary relationship and the practice of embassy visits were, therefore, the reason for all of the ensuing disputes over thefts and losses.

In this way, trade and tribute, two key elements of Qing foreign policy, complemented each other to form a commercial web spanning the boundary between the two neighbors. Equally, it is important to note that these commercial relations between the subjects of the Qing and those of the Chosonn were framed by the asymmetrical power relationship between the suzerain court and the tributary state. The procedure for settling disputes, which was initiated, carried out, and concluded by the Qing court, demonstrates the political hierarchy inherent in the tributary relationship. Problems experienced by the Koreans, such as the rampant corruption among the Qing officials encountered by the Chosonn embassies and the Chosonn king's frustration with the punishment of his own officials, were never raised in discussions with the Shenging military governor or the Qianlong emperor. The tributary relationship required commercial exchange, but this economic connection was built and maintained on the premise of a firm political hierarchy. 